\title{
Spatial distributions of floating seaweeds in the East China Sea from late winter to early spring
}

\author{
S. Mizuno • T. Ajisaka • S. Lahbib • Y. Kokubu • \\ M. N. Alabsi • T. Komatsu
}

Received: 26 May 2013 /Revised: 25 August 2013 / Accepted: 26 August 2013 / Published online: 12 November 2013

(C) The Author(s) 2013. This article is published with open access at Springerlink.com

\begin{abstract}
Floating seaweeds play an important role as a habitat for many animals accompanying or attaching to them in offshore waters. It was in 2000 that the first report described abundant distributions of floating seaweeds in offshore waters in the East China Sea in spring. Young individuals of the yellowtail Seriola quinqueradiata are captured for aquaculture purposes from floating seaweeds in the East China Sea. Therefore, a sound understanding of the distributions of floating seaweeds in the East China Sea is needed. Detailed information is especially important during the late winter to early spring, which corresponds to the juvenile period of the yellowtail. Thus, field surveys using $\mathrm{R} / \mathrm{V}$ Tansei-Maru were conducted in the Japanese Exclusive Economic Zone in the East China Sea from late winter to early spring in 2010 and 2011. We obtained positions of the vessel by GPS and transversal distances from the vessel to a raft by visual observation. Distance sampling method (Thomas et al. 2010) was applied to estimation of floating seaweed densities (rafts km${ }^{-2}$ ). Seaweed rafts were also randomly sampled using nets during the research cruises. In the East China Sea, seaweed rafts were distributed mainly on the continental shelf west of the Kuroshio, especially in waters between $26^{\circ} \mathrm{N}$ and $30^{\circ} \mathrm{N}$. Collected rafts consisted of only one species, Sargassum horneri (Turner) C. Agardh. Taking into account surface currents and geographical distribution of $S$. horneri, it is estimated that these floating seaweeds originated from natural beds along the coast between mid and south China. Considering the approximate travel times, it is suggested that floating
\end{abstract}

S. Mizuno $(\bowtie) \cdot$ S. Lahbib $\cdot$ Y. Kokubu $\cdot$ M. N. Alabsi $\cdot$ T. Komatsu Atmosphere and Ocean Research Institute, University of Tokyo, 5-1-5, Kashiwanoha, Kashiwa, Chiba 277-8564, Japan e-mail: walking712@gmail.com

T. Ajisaka

Kyoto University, Oiwake, Kitashirakawa, Sakyou, Kyoto, Kyoto 606-8502, Japan patches are colonized by yellowtails early on during their trips, i.e., close to the Chinese coast.

Keywords Floating seaweed $\cdot$ Sargassum horneri $\cdot$ East China Sea $\cdot$ Biomass $\cdot$ Kuroshio

\section{Introduction}

Floating seaweeds are an important habitat for many accompanying or attached animals in offshore waters. Among natural floating objects, macroalgae probably represent the quantitatively most important substrata (Thiel and Gutow 2005). Several studies have highlighted the importance of rafting as a habitat for marine invertebrates and some fish species (Safran and Omori 1990; Ingólfsson 1995; Sano et al. 2003). Such floating seaweeds generally originate in benthic beds of macroalgae in coastal areas. Species comprising floating seaweed patches differ substantially between oceans. For example, Ascophyllum nodosum and Fucus vesiculosus have been abundantly reported from the North Atlantic coasts (Ingólfsson 1995; Vandendriessche et al. 2006; Thiel et al. 2011) and Macrocystis pyrifera along the Californian and Chilean coast (Hobday 2000; Hinojosa et al. 2011). In the Sargasso Sea and northwestern Pacific, Sargassum species are the dominant floating seaweeds, especially around Japan (Yoshida 1963). In the Sargasso Sea, floating seaweeds pass their entire life in floating state through vegetative reproduction (Parr 1939). On the other hand, floating seaweeds distributed around Japanese waters originally grow in benthic habitats.

Sargassum species growing on rocky coasts form a luxuriant forest in spring and a scanty one in summer in the northwestern Pacific (Komatsu et al. 1982). Thus benthic Sargassum forests have great influences on marine environments in spring such as water temperature (Komatsu et al. 
1982; Komatsu 1985; Komatsu et al. 1994), pH (Komatsu and Kawai 1986), dissolved oxygen content of seawater (Komatsu 1989), downward illumination (Komatsu 1989), and water flow (Komatsu and Murakami 1994). During their maturation season from winter to spring when they become longer, waves and currents detach the seaweeds above or with holdfast on the bottom. This is because their drag force becomes greater than the attachment force due to higher buoyancy of large individuals, produced by their numerous gas vesicles (Yoshida 1963). Most Sargassum species can float after being detached from the bottom due to vesicles. Thus they contribute to the stocks of floating seaweeds in waters around Japan (Yoshida 1963), occasionally reaching similar extensions as observed in the Sargasso Sea (Parr 1939).

Floating seaweeds play ecologically important roles in offshore waters. They serve as spawning substratum for flying fish and Pacific saury (Ikehara and Sano 1986). Around Japan, one of the commercially most important pelagic fish, the yellowtail Seriola quinqueradiata, also associates with seaweed rafts for reproductive purposes. Juvenile $S$. quinqueradiata start to accompany floating seaweeds 1 month after hatching and leave them when their size attains $150 \mathrm{~mm}$ body length (Safran 1990; Sakakura and Tsukamoto 1997). During the spring, fishermen catch wild juveniles accompanying floating seaweeds by scooping up these rafts together with the juvenile fishes, which are then used for aquaculture. This occurs especially in waters off Kyushu Island including the East China Sea since1960s because the aquaculture of yellowtail depends on wild juveniles accompanying floating seaweeds. The dependence on wild seedstock is due to their cannibalism during its larvae and juvenile periods, which makes it difficult to produce artificial seedstock. Yellowtails spawn in the region between the continental shelf and the oceanic front of the Kuroshio Current in the East China Sea from late winter to spring (Yamamoto et al. 2007). The earliest Yellowtail larvae hatch in the end of January.

Yoshida (1963) reported that most floating seaweeds around Japan are found in nearshore coastal waters, within $20 \mathrm{~km}$ from the shore, especially in areas where oceanic fronts come close to the coast. One important reason for the patchiness of floating items, such as macroalgae as well as any other floating objects, is their accumulation at fronts between two different water masses (Witherington 2002; Acha et al. 2003; Hinojosa et al. 2010). However, Senta (1965) reported that massive amounts of floating seaweeds could not be found in the front between coastal waters and Kuroshio Current in the East China Sea. Recently, Komatsu et al. (2007) surveyed seaweed rafts in the eastern East China Sea in March and May and reported that they were distributed in waters on the continental shelf west of the Kuroshio front (Komatsu et al. 2007). Taking into account the yellowtail spawning season in the East China Sea, the juvenile starts to accompany seaweed rafts in February. Hanaoka et al. (1986) reported that survival rates of the juvenile reared with seaweed rafts or artificial seaweed rafts made by cellulose are higher than without rafts. It is suggested that floating seaweeds reduce cannibalism of yellowtail juveniles. Thus, it is very important to know the distributions of seaweed rafts in the East China Sea in February and early March. However, it was not well known whether abundant patches of floating seaweeds can be found in the East China Sea in February and early March. This study thus aimed to elucidate the distribution of floating seaweeds in the East China Sea in February and March by visual census and towed net samples.

\section{Materials and methods}

\section{Research cruises}

Two research cruises using R/V Tansei Maru were organized to survey floating seaweeds in the East China Sea in late winter to early spring. One was KT10-1 research cruise from 22 February to 6 March 2010 and the other was KT11-1 from 18 to 23 February 2011. The observation course was planned to cover the waters west of Kyushu Islands and the area between the Kuroshio Current and the continental shelf in the eastern East China Sea within the Exclusive Economic Zone of Japan. Visual census of seaweed rafts were conducted from the deck of R/V Tansei Maru at a height of $11.5 \mathrm{~m}$ above the sea surface under good conditions (i.e., wave height less than $1 \mathrm{~m}$ ), and from sunrise to sunset during the two cruises. The vessel navigated along designed transects. The following information was recorded at each occurrence of floating seaweeds: time, perpendicular distance from the vessel to a seaweed raft, and its diameter. The distance and diameter were estimated by trained researchers.

During both cruises, seaweed rafts were sampled at 12 locations in February and March 2010 and 16 locations in February 2011 (Fig. 1). Some seaweed rafts were sampled randomly by using dip net or towing an ORI ring net, coneshaped plankton net, with a diameter of $1.6 \mathrm{~m}$, and mesh size $1 \mathrm{~mm}$. Sampled floating seaweeds were divided into individual plants on the deck of the vessel to identify species composition. After species identification the wet weight of each individual plant was measured with the aid of a spring scale on the deck.

Floating seaweed abundance was estimated by the line transect method using distance sampling (Buckland et al. 2001). This method uses the perpendicular distance from the transect line to the object and diameter of the object to correct for visibility bias, and allows estimating the probability of detecting objects and corrected densities. Densities were computed using the software DISTANCE version 6.0. Release 2 (Thomas et al. 2010). The probability of floating seaweed detection was estimated with models combining density 
Fig. 1 Map showing sampling stations in the East China Sea and Pacific Ocean south of Shikoku Island. Triangles and circles indicate stations in 2010 and 2011, respectively. Filled and open marks are stations where floating seaweed rafts consists of only $S$. horneri and many seaweed species, respectively

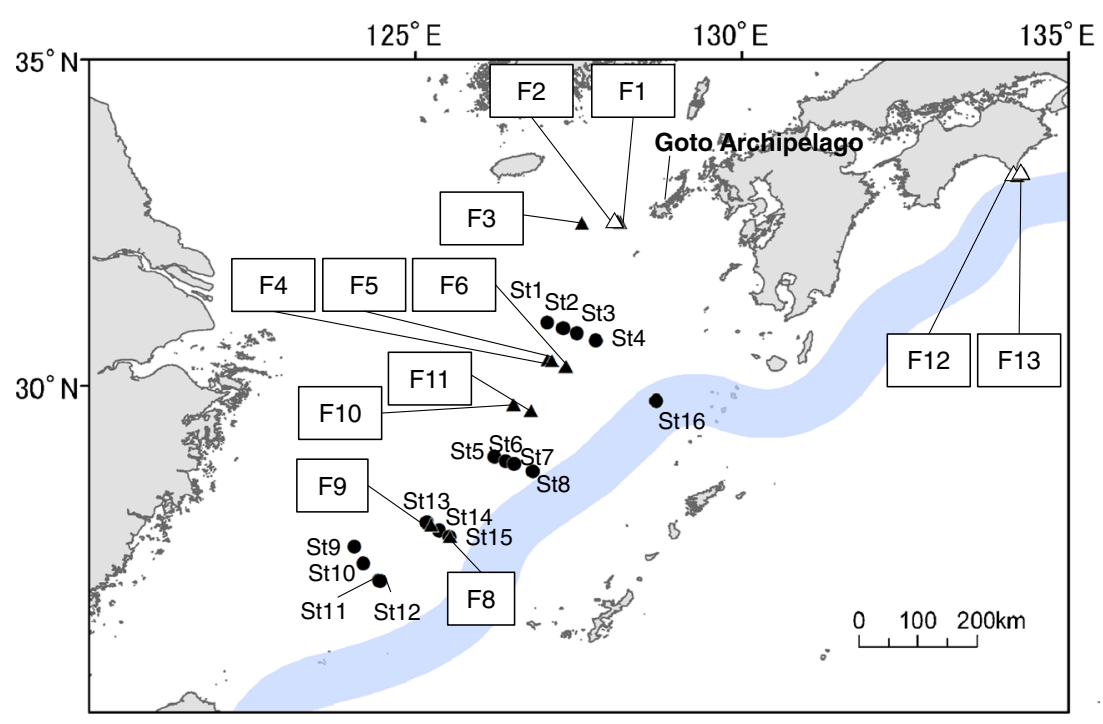

function (uniform, half-normal, and hazard-rate) with adjustments (cosine, simple, and Hermite polynomials). Following Thomas et al. (2002), we estimated the parameter $\widehat{\mu}$ called the effective strip half-width (ESW), and defined as the maximum limit for distinction.

$\widehat{D}=\frac{n}{2 \widehat{\mu} L}$

where $\widehat{D}, n$, and $L$ represent the abundance of seaweed rafts, the total number of rafts of floating seaweeds along a transect, and the length of the transect, respectively. In order to take into account the lack of homogeneity at sea and meteorological conditions between transects, the model was fitted to data separately for each transect. Akaike's Information Criterion (AIC) provides an objective, quantitative method for model selection. Estimates from the model with the lowest AIC [defined by Eq. 2] were selected (Buckland et al. 2001).

$\mathrm{AIC}=-2 \log _{e}(\Lambda)+2(q)$

where $\Lambda$ is the maximized likelihood and $q$ the number of estimated parameters. This number of estimated parameters was the number of parameters based on combination keyfunction and adjustment-term provided by the program DISTANCE. The maximized likelihood was obtained from maximum likelihood estimation (Buckland et al. 2001). Rafts of floating seaweeds were classified into four classes depending on the perpendicular distances from the vessel to a raft, $0-10$, 10-20, 20-30, and 30-40 m. Rafts more than $40 \mathrm{~m}$ distant from the vessel were neglected due to the uncertainty of measuring distance. Calculation results for each model are indicated in Tables 3 and 4. The number of rafts within the effective strip half-width was obtained from the best fitted model. The population mean for the wet weight along each transect in the surveys of 2010 and 2011 was estimated by using the relation between diameter and wet weight of seaweed rafts collected during both surveys of 2010 and 2011 . The diameter of floating seaweeds was converted to wet weight using the equation representing this relation. The mean wet weight $(M)$ of all rafts along each transects was calculated. Standing crop $(\mathrm{Sc})$ along a transect was calculated from $\widehat{D}$, the density of rafts, obtained by the program DISTANCE, and $M$, the mean wet weight of the rafts, estimated from the observation.

$\mathrm{Sc}\left(\mathrm{kgWW} \mathrm{km}^{-2}\right)=\widehat{D}\left(\mathrm{raft} \mathrm{km}^{-2}\right) \times M\left(\mathrm{~kg} \mathrm{WW} \mathrm{raft}^{-1}\right)$

The total biomass along a transect $(\mathrm{Tb})$ was calculated by multiplying the standing crop (Sc) by the survey area $(A)$.

$\mathrm{Tb}(\mathrm{kgWW})=\mathrm{Sc}\left(\mathrm{kgWW} \mathrm{km}^{-2}\right) \times A\left(\mathrm{~km}^{-2}\right)$

where Sc and $A$ are standing crop of floating seaweeds along a transect and survey area obtained from $\widehat{\mu}$ and $L$, respectively.

\section{Results}

Distribution of floating seaweeds

In the East China Sea, floating seaweeds were quite abundant in February and early March. Most floating seaweeds observed in both years were distributed in waters on the continental shelf less than $200 \mathrm{~m}$ deep, which is the western edge of the Kuroshio Current in the East China Sea except in the waters south of Kyushu Island (Fig. 2). Although floating objects were observed on all transects, no floating seaweeds 
Fig. 2 Visual survey transects for floating seaweed rafts (solid lines) in the East China Sea during R/V Tansei Maru cruises of KT10-1 (a) and KT11-1 (b), and floating seaweed rafts (green circle) in intervals of $20 \mathrm{~km}$ distance of transect. Size of circle depends on number of rafts. Black dash line represents $200 \mathrm{~m}$ isobaths
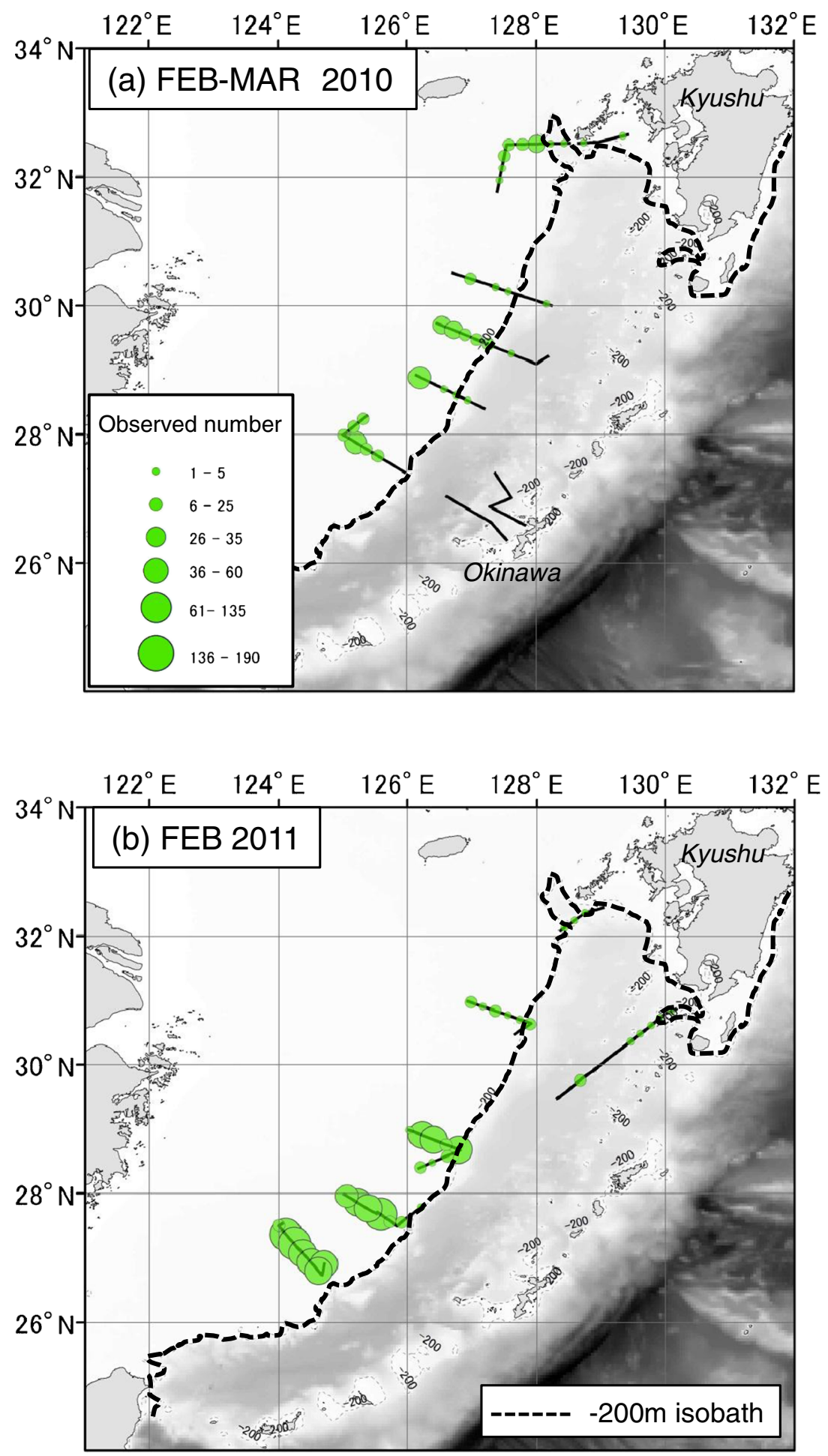

occurred along the two transects located in waters east of Kuroshio Current (Fig. 2a).

In 2010, three species of Sargassum, one Rhodophyceae species and one Ulvales species were observed at Stn. F2 near Goto Archipelago (Table 1 and Fig. 1). Three Sargassum species were present at Stn. F12. Nine Sargassum species, one Colpomenia species, and one seagrass species were present at Stn. F13. Both stations were located close to the Cape of Murotomisaki south of Shikoku island. More than one algal species was observed in waters close to the Japanese coast (shown as open triangle in Fig. 1). On the other hand, only S. horneri was found at Stns. F1, F3, F4, F5, F6, F8, F9, F10, F11, and all station on February 2011 (Table 1 and 2). All these stations were included in the East China Sea. 
Table 1 Species of floating seaweed rafts and their number of individuals during KT10-1

\section{KT10-1}

Species name

\begin{tabular}{|c|c|c|c|c|c|c|c|c|c|c|c|}
\hline \multicolumn{12}{|c|}{ Station } \\
\hline \multirow[t]{5}{*}{ F1 } & $\mathrm{F} 2$ & F3 & F4 & F5 & F6 & F8 & F9 & F10 & F11 & F12 & F13 \\
\hline & & & & & & & & & & & 1 \\
\hline & 1 & & & & & & & & & & \\
\hline & & & & & & & & & & & $6(4)$ \\
\hline & $1(1)$ & & & & & & & & & & 1 \\
\hline \multirow[t]{10}{*}{$2^{\mathrm{a}}$} & $25^{\mathrm{a}}$ & $10^{\mathrm{a}}$ & $13^{\mathrm{a}}$ & $5^{a}$ & $21^{\mathrm{a}}$ & $60^{\mathrm{a}}$ & $136^{\mathrm{a}}$ & $51^{\mathrm{a}}$ & $111^{\mathrm{a}}$ & 3 & $6(3)$ \\
\hline & 1 & & & & & & & & & & \\
\hline & & & & & & & & & & & 1 \\
\hline & & & & & & & & & & 7 & $10(1)$ \\
\hline & & & & & & & & & & & $1(1)$ \\
\hline & & & & & & & & & & 1 & $5(1)$ \\
\hline & & & & & & & & & & & 1 \\
\hline & & & & & & & & & & $42^{\mathrm{a}}(34)$ & $138^{\mathrm{a}}(97)$ \\
\hline & 1 & & & & & & & & & & \\
\hline & & & & & & & & & & & 9 \\
\hline
\end{tabular}

Colpomenia sinuosa (Mertens ex Roth) Derbes et Solier Rhodophyceae sp

Sargassum filicinum Harvey

S. fulvellum (Turner) C. Agardh

S. fusiforme (Harvey) Setchell

S. horneri (Turner) C. Agardh

S. micracanthum Endlicher

S. muticum (Yendo) Fensholt

S. patens C. Agardh

S. siliquastrum (Turner) C. Agardh

S. fulvellum (Turner) C. Agardh

S. thunbergii (Mertens ex Roth) Kuntze

S. yamamotoi Yoshida

Ulvales $\mathrm{sp}$

Zostera marina L.

Number in parenthesis shows number of individuals with holdfast

${ }^{\text {a }}$ Dominant species

Some seaweeds at Stns. F2, F12, and F13 still had their holdfasts (Table 1). These stations are located in coastal waters close to the shore. Distances of these stations to the nearest land are about 48, 4, and $12 \mathrm{~km}$, respectively (Fig. 1). On the other hand, $S$. horneri collected at all stations on KT10-1 and KT11-1 had no holdfasts, except at Stn. F13 near the coast. Temperature of sampling stations ranged 16.8 to $22.8^{\circ} \mathrm{C}$ in 2010 and 15.3 to $18.4^{\circ} \mathrm{C}$ in 2011 .

To obtain the relationship between the diameter of a raft and its weight, we applied various models to fit their distributions (Fig. 3). The exponential model was selected as a suitable model to explain the relationship between diameter (Di) and wet weight $(\mathrm{Wt})$ of seaweed rafts: $\mathrm{Wt}=368.64 \mathrm{Di}^{3}+$ $379.25 \mathrm{Di}^{2}+1,755.1 \mathrm{Di}\left(R^{2}=0.796\right)$. This relationship permits us to estimate the mean wet weight of seaweed rafts based on the estimated diameter.
Abundance of floating seaweeds

In February and March 2010, ESW values for all transects ranged from 11.4 to $25.7 \mathrm{~m}$ (Table 3). Raft density of floating seaweed along the transect on 2 March was highest among transects in 2010 (Table 3). This transect was located southernmost in the survey area of 2010. The mean wet weight per raft was $3.86 \mathrm{~kg}$ (Table 3), and the estimated biomass for this transect was $100.36 \mathrm{~kg} \mathrm{ww} \mathrm{km}^{-2}$ (Fig. 4b).

In February 2011, ESW values for all transects ranged from 11.0 to $17.8 \mathrm{~m}$. Density of floating seaweeds along the 21 February located southernmost in survey area of 2011 was extremely high (Table 4). Total biomass of this transect was the highest, $504.12 \mathrm{~kg} \mathrm{ww} \mathrm{km}^{-2}$ (Fig. 4c).

In both surveys of 2010 and 2011, the maximum biomass of floating seaweeds consisting of only $S$. horneri was

Table 2 Species of floating seaweed rafts and their stipe numbers during KT11-1

\section{KT11-1}

\begin{tabular}{|c|c|c|c|c|c|c|c|c|c|c|c|c|c|c|c|c|}
\hline \multirow[t]{2}{*}{ Species name } & \multicolumn{16}{|c|}{ Station } \\
\hline & St1 & St2 & $\mathrm{St} 3$ & St 4 & St5 & St6 & $\mathrm{St} 7$ & St8 & St9 & St10 & St11 & St12 & St13 & St14 & St15 & St16 \\
\hline S. horneri (Turner) C. Agardh & $2^{\mathrm{a}}$ & $4^{\mathrm{a}}$ & $2^{a}$ & $1^{\mathrm{a}}$ & $5^{\mathrm{a}}$ & $2^{a}$ & $10^{\mathrm{a}}$ & $10^{\mathrm{a}}$ & $15^{\mathrm{a}}$ & $6^{\mathrm{a}}$ & $9^{\mathrm{a}}$ & $7^{\mathrm{a}}$ & $16^{\mathrm{a}}$ & $2^{a}$ & $14^{\mathrm{a}}$ & $2^{\mathrm{a}}$ \\
\hline
\end{tabular}

No individuals with holdfast

${ }^{\text {a }}$ Dominant species 


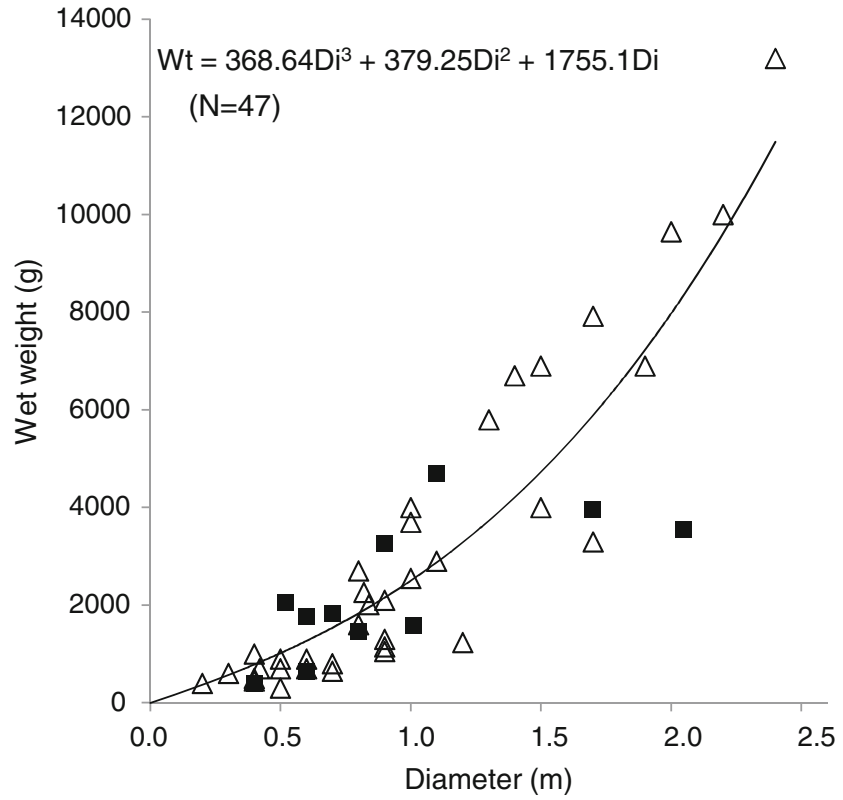

Fig. 3 Regression curve $\left(R^{2}=0.796\right)$ showing the relation between diameter $(D i)$ and wet weight $(W t)$ of floating seaweed rafts collected during the R/V Tansei Maru cruises of KT10-1 (closed squares) and KT11-1 (open triangles)

distributed in waters on the continental shelf west of the Kuroshio Current around $25^{\circ} \mathrm{N}$ and $127^{\circ} \mathrm{E}$.

\section{Discussion}

Floating seaweeds consist of several Sargassum species in coastal waters of Japan (Yoshida 1963). Ohno (1984) observed floating seaweeds south of Kyusyu and Shikoku Island and reported that those in the coastal waters were composed of two to six species. Hirata et al. (2001) investigated seasonal changes of the species composition of floating seaweeds in the coastal waters of Izu Peninsular, central Japan. They stated that the number of species of floating plants in one patch ranged from one to 11. Hirosaki (1963) and Gamo and Matsuura (1975) also investigated seasonal changes in the species composition of floating seaweeds in coastal waters around Japan, and found that floating seaweeds consisted of multiple seaweed species. On the other hand, Komatsu et al. (2007) reported that floating seaweeds in offshore waters of the East China Sea in mid March and May were only $S$. horneri. The species composition in that study was similar as that observed herein. Thus, the floating seaweeds in offshore waters of the East China Sea in February and early March are also characterized by $S$. horneri, same as those in mid March and May.

$S$. horneri growing in benthic habitats along the coasts east of the East China Sea are not distributed from south of Kyushu Island to Taiwan through Ryukyu Archipelago (Yoshida 1998 ) although the species composition of floating seaweeds in coastal waters around Japan is affected by the flora of surrounding waters (Hirata et al. 2001). Considering the benthic distribution of $S$. horneri along the coasts around the East China Sea (Tseng 1983) and the northeastward surface currents, such as the Kuroshio Current and Taiwan Warm Current in offshore waters of the East China Sea in spring (Zhu et al. 2004), the possible origin of floating $S$. horneri in offshore waters of the East China Sea in February and early March is suspected to be the Chinese coast, similar as suggested by Komatsu et al. (2007) for mid March and May. It appears that the supply of floating seaweeds distributed in the East China Sea depends on the benthic populations of $S$. horneri along the Chinese coast.

In previous surveys conducted in nearshore waters around Japan, it is reported that floating seaweeds consisted of Sargassum individuals with holdfasts (Ohno 1984; Yatsuya 2005). Our study showed that no holdfasts were found in offshore waters in the East China Sea. Komatsu et al. (2007) deployed satellite tracking buoys attached to rafts of $S$.

Table 3 Results for models applied to the distribution of floating seaweed rafts along each transect during February and March 2010 by the program DISTANCE v6.0 R2

\begin{tabular}{|c|c|c|c|c|c|c|c|c|c|}
\hline Date & Model (key + adjustment) & ESW & $\begin{array}{l}\text { Length of } \\
\text { transect }(\mathrm{km})\end{array}$ & $\begin{array}{l}\text { Number } \\
\text { of rafts }\end{array}$ & $\begin{array}{l}\text { Estimated mean wet weight } \\
\left(\mathrm{kg} \mathrm{WW} \text { ind }^{-1}\right) \text { of rafts }\end{array}$ & $\mathrm{D}$ & D LCL & D UCL & $\mathrm{DCV}$ \\
\hline $22 \mathrm{Feb}$ & Half + Hermite & 11.4 & 86.87 & 3 & 3.34 & 1.5 & 0.2 & 9.6 & 0.45 \\
\hline $23 \mathrm{Feb}$ & Half + Cos & 13.8 & 179.74 & 88 & 1.58 & 17.7 & 14.1 & 22.3 & 0.12 \\
\hline $24 \mathrm{Feb}$ & Unifo + Cos & 25.7 & 159.33 & 14 & 1.86 & 1.7 & 1.1 & 2.7 & 0.22 \\
\hline $25 \mathrm{Feb}$ & Half + Hermite & 16.3 & 117.64 & 59 & 1.90 & 15.2 & 12.4 & 18.6 & 0.10 \\
\hline $2 \mathrm{Mar}$ & Half + Hermite & 16.0 & 166.73 & 137 & 3.86 & 26.0 & 22.8 & 29.6 & 0.07 \\
\hline 3 Mar & Hazard + Cos & 15.9 & 190.51 & 95 & 1.44 & 15.7 & 13.4 & 18.4 & 0.08 \\
\hline 4 Mar & Unifo + Simple & 17.2 & 234.68 & 16 & 2.49 & 1.9 & 1.5 & 2.6 & 0.13 \\
\hline
\end{tabular}

AIC Akaike's Information Criteria, $E S W$ effective strip width, $n$ total number of rafts within ESW, $D$ density of rafts, $D L C L$ lower confidence limit of D, $D U C L$ upper confidence limit of D, D CV coefficient of variation of D Half, Unifo, Hermite, Cos and Hazard are Half-normal, Uniform, Hermite, Cosine and Hazard-rate distributions, respectively 
Fig. 4 Estimated biomass of floating seaweeds ( $\mathrm{kg} \mathrm{ww} \mathrm{km}^{-2}$ ) along the observation transects (solid lines) during $\mathrm{R} / \mathrm{V}$ Tansei Maru. Cruises of KT10-1 in February 2010 (a), March 2010 (b), and KT11-1 in February 2011 (c). Light blue stripe represents the path of Kuroshio Current. (source: Hydrographic and Oceanographic Department of Japan Coast Guard, 2010 and 2011)
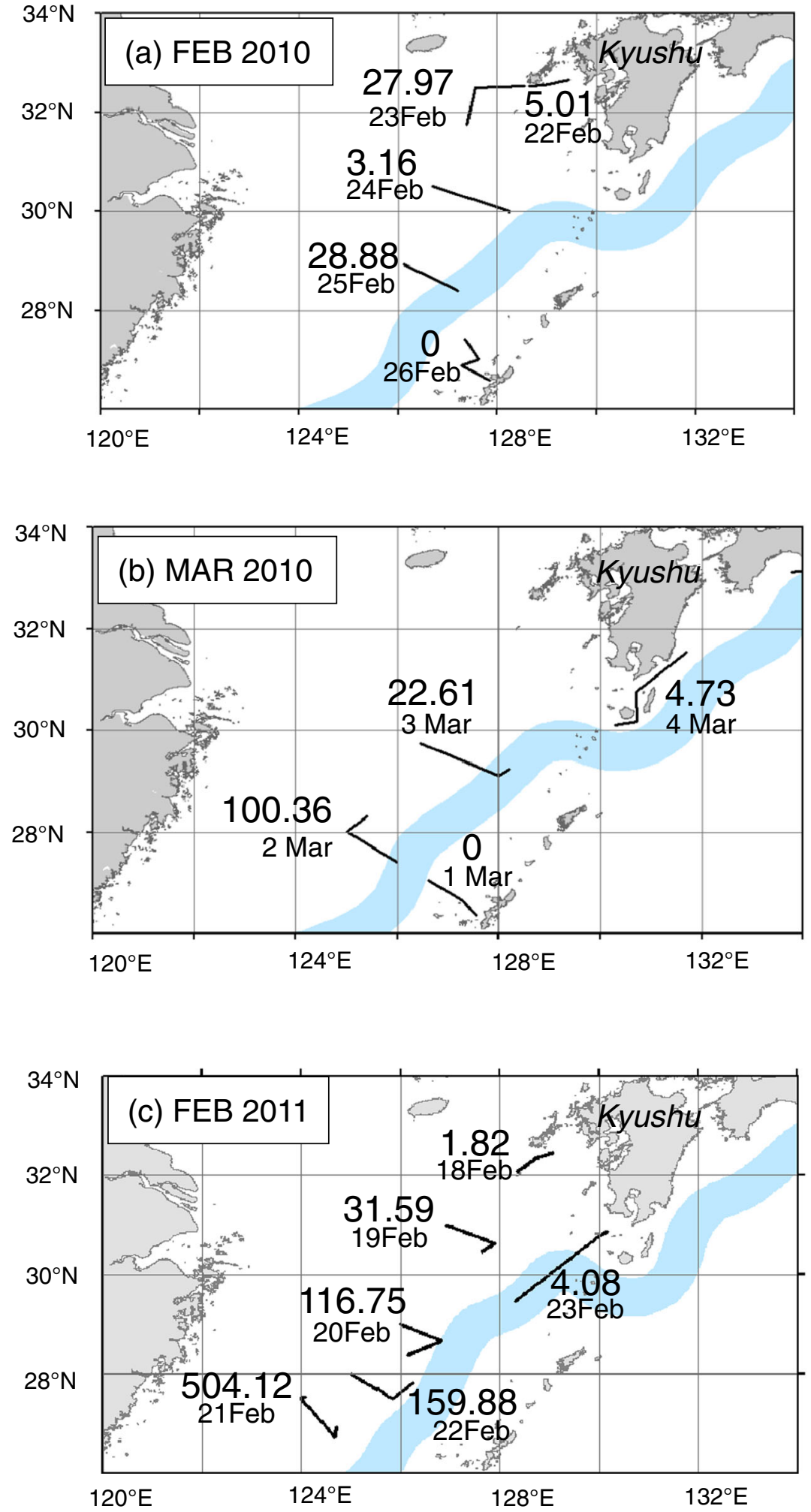

horneri from the Chinese coast. It took about 1 to 2 months for the buoys to move from the Chinese coast to offshore waters with currrents in the East China Sea. This suggests that long-distance dispersal of floating Sargassum is accompanied by damage and loss of gas vesicles. Since the holdfasts have negative buoyancy, it is possible that floating seaweeds of $S$. horneri with a holdfast have sunk before reaching offshore waters because of their negative densities caused by the loss of gas vesicles. Yatusya (2008) reported S. horneri had lower density and longer floating periods than other Sargassum 
Table 4 Results for models applied to the distribution of floating seaweed rafts along each transect during February 2012 by the program DISTANCE v6.0 R2

\begin{tabular}{|c|c|c|c|c|c|c|c|c|c|}
\hline Date & $\begin{array}{l}\text { Model (key + } \\
\text { adjustment) }\end{array}$ & ESW & $\begin{array}{l}\text { Length of } \\
\text { transect }(\mathrm{km})\end{array}$ & $\begin{array}{l}\text { Number } \\
\text { of rafts }\end{array}$ & $\begin{array}{l}\text { Estimated mean wet weight } \\
\left(\mathrm{kg} \mathrm{WW} \mathrm{ind}^{-1}\right) \text { of rafts }\end{array}$ & $\mathrm{D}$ & D LCL & D UCL & D CV \\
\hline $18-\mathrm{Feb}$ & Unifo/ Cos & 14.7 & 79.97 & 4 & 1.07 & 1.7 & 0.4 & 7.1 & 0.34 \\
\hline 19-Feb & Hazard / Cos & 11.0 & 134.16 & 47 & 1.98 & 16.0 & 6.3 & 40.6 & 0.49 \\
\hline 20-Feb & Half / Cos & 17.8 & 162.46 & 351 & 2.63 & 60.7 & 52.6 & 69.9 & 0.07 \\
\hline 21-Feb & Half / Cos & 14.4 & 138.46 & 878 & 2.29 & 220.2 & 204.3 & 237.4 & 0.04 \\
\hline 22-Feb & Hazard / Cos & 17.1 & 159.36 & 397 & 1.60 & 72.8 & 63.7 & 83.1 & 0.07 \\
\hline 23-Feb & Half / Hermite & 17.4 & 237.40 & 20 & 1.69 & 2.4 & 1.7 & 3.5 & 0.18 \\
\hline
\end{tabular}

Abbreviations are identical to the ones in Table 3

species. Consequently, the floating individuals of $S$. horneri without holdfast can be transported far from their original habitats on rocky shores. Studies on other floating macroalgae also show that at larger distances from potential source regions, these are more overgrown by epibionts and floating individuals are more disintegrated (Rothäusler et al. 2011; Tala et al. 2013).

Floating seaweeds were rarely observed within the Kuroshio Current Proper. No floating seaweeds were observed along the two transects located in the Kuroshio Current and east of the Kuroshio Current in February to March of 2010. This is also true in surveys of floating seaweeds in mid March of 2004 and May of 2002 (Komatsu et al. 2008). Floating seaweeds apparently do not cross the Kuroshio Current from the continental shelf to outer waters east of the Kuroshio Current. Thus, they are generally retained in the convergence region between warmer water of the Kuroshio Current and colder waters of the continental shelf.

The number of observed seaweed rafts tended to increase in the southward direction. The highest biomass of floating seaweeds was located at the southernmost transect on the continental shelf in surveys of 2010 and 2011. Komatsu et al. (2008) reported that the biomass of floating seaweeds in the southernmost transect $\left(20.35 \mathrm{~kg}\right.$ ww km ${ }^{-2}$, around $30^{\circ}$ $\mathrm{N}, 127^{\circ} \mathrm{E}$ ) was greater than in the transect located west of Kyushu $\left(2.18 \mathrm{~kg} \mathrm{ww} \mathrm{km}{ }^{-2}\right)$ in mid March. In all of the surveyed month, there were floating seaweeds in offshore water in the East China Sea much more than coastal water around Kyusyu Island in February and early March.

In the East China Sea, yellowtail starts to spawn in waters southeast of continental shelf edge in late January. Yellowtail juveniles have been collected in surface water temperatures between 14 and $26{ }^{\circ} \mathrm{C}$ (Yamamoto et al. 2007). Optimal growth rates of yellowtail juveniles are at a temperature of around $22{ }^{\circ} \mathrm{C}$ (Fujimoto et al. 2006). Since yellowtail juveniles were also collected with floating seaweeds in this study, it is suggested that the juveniles retained on the spawning grounds by eddies start to accompany floating seaweeds in waters southeast of the continental shelf where sea surface temperatures are optimal for their growth. Thus, yellowtail juveniles spawned earliest in the East China Sea utilize floating seaweeds distributing on the continental shelf in the East China Sea as their nursery in February and early March. Floating S. horneri in the East China Sea plays an indispensable role as nursery habitat for commercially important species in February and early March. It is important to identify their source populations along the Chinese coast and to conserve $S$. horneri beds that support the unique ecosystem of floating seaweeds in the East China Sea.

Acknowledgments The authors would like to thank the captain and crew of R/V Tansei Maru, Japan Agency For Marine-Earth Science and Technology. They express sincere appreciation to the researchers who helped them with observation and sampling of floating seaweeds. This work was supported by JSPS Grant-in-Aid for Scientific Research (A) grant number 22255010 .

Open Access This article is distributed under the terms of the Creative Commons Attribution License which permits any use, distribution, and reproduction in any medium, provided the original author(s) and the source are credited.

\section{References}

Acha EM, Mianzan HW, Iribarne O, Gagliardini DA, Lasta C, Daleo P (2003) The role of the Río de la Plata bottom salinity front in accumulating debris. Mar Pollut Bull 46:197-202

Buckland ST, Anderson DR, Burnham KP, Laake JL, Borchers DL, Thomas L (2001) Introduction to distance sampling - estimating abundance of biological populations. Oxford University Press, New York, p 432pp

Fujimoto H, Yamamoto Y, Yamazaki H, Sakiyama K, Takahashi M, Nishioka T, Shiozawa S (2006) Development on technology for yellowtail seedling production. Fisheries Research Agency, Kanagawa (in Japanese)

Gamo S, Matsuura M (1975) Observations on the drifting seaweeds and the animals found in their masses in Sagami and Suruga Bays. Departmental Bull Pap 22:7-11 (in Japanese with English abstract)

Hanaoka F, Konishi Y, Kotoh T (1986) Swarming reaction of wild juvenile to artificial drifting seaweed. Marine Ranching Program progress report, jack mackerel 4:19-29 (in Japanese) 
Hinojosa IA, Pizarro M, Ramos M, Thiel M (2010) Spatial and temporal distribution of floating kelp in the channels and fjords of southern Chile. Estuarine Coastal Shelf Sci 87:367-377

Hinojosa IA, Rivadeneira MM, Thiel M (2011) Temporal and spatial distribution of floating objects in coastal waters of central-southern Chile and Patagonian fjords. Cont Shelf Res 31:172-186

Hirata T, Tanaka J, Iwami T, Ohmi T, Dazai A, Aoki M, Ueda H, Tsuchiya Y, Sato T, Yokohama Y (2001) Ecological studies on the community of drifting seaweeds in the south-eastern coastal waters of Izu Peninsula, central Japan I: Seasonal changes of plants in species composition, appearance, number of species and size. Phycol Res 49:215-229

Hirosaki Y (1963) Ecological study on Fishes with the drifting seaweeds. II Records of weeds and fishes. Res Sci Rep 61:77-90 (in Japanese)

Hobday AJ (2000) Abundance and dispersal of drifting kelp Macrocystis pyrifera rafts in the Southern California Bight. Mar Ecol Prog Ser 195:101-116

Ikehara K, Sano O (1986) Distribution and species composition of floating seaweeds collected in the Sado Straits of the Japan Sea. Bull Jap Sea Reg Fish Res Lab 36:59-76 (in Japanese with English abstract)

Ingólfsson A (1995) Floating clumps of seaweed around Iceland: natural microcosms and a means of dispersal for shore fauna. Mar Biol 122: $13-21$

Komatsu T (1985) Temporal fluctuations of water temperature in a Sargassum forest. J Oceanogr Soc Jpn 41:235-243

Komatsu T (1989) Day-night reversion in the horizontal distributions of dissolved oxygen content and $\mathrm{pH}$ in a Sargassum forest. J Oceanogr Soc Jpn 45:106-115

Komatsu T, Ariyama H, Nakahara H, Sakamoto W (1982) Spatial and temporal distributions of water temperature in a Sargassum forest. J Oceanogr Soc Jpn 38:63-72

Komatsu T, Kawai H (1986) Diurnal changes of $\mathrm{pH}$ distributions and the cascading of shore water in a Sargassum forest. J Oceanogr Soc Jpn 42:447-458

Komatsu T, Tatsukawa K, Filippi JB, Sagawa T, Matsunaga D, Mikami A, Ishida K, Ajisaka T, Tanaka K, Aoki M, Wang WD, Liu HF, Zhang SD, Zhou MD, Sugimoto T (2007) Distribution of drifting seaweeds in eastern East China Sea. J Mar Syst 67:245-252

Komatsu T, Matsunaga D, Mikami A, Sagawa T, Boisnier E, Tatsukawa K, Aoki M, Ajisaka T, Uwai S, Tanaka K, Ishida K, Tanoue H, Sugimoto T (2008) Abundance of drifting seaweeds in eastern East China Sea. J Appl Phycol 20:801-809

Komatsu T, Murakami S (1994) Influence of a Sargassum forest on the spatial distribution of water flow. Fish Ocenogr 3:256-266

Komatsu T, Murakami S, Kawai H (1994) Some features of jump of water temperature in a Sargassum forest. J Oceanogr 52:109-124

Ohno M (1984) Algological observation on the floating seaweeds of off shore water of Shikoku Island in Japan. Bull Jpn Soc Sci Fish 50: 1653-1656

Parr AE (1939) Quantitative observations on the pelagic Sargassum vegetation of the western North Atlantic. Bull Bingham Oceanogr Coll 6:1-94

Rothäusler E, Gómez I, Hinojosa IA, Karsten U, Miranda L, Tala F, Thiel M (2011) Kelp rafts in the Humboldt Current: interplay of abiotic and biotic factors limit their floating persistence and dispersal potential. Limnol Oceanogr 56:1751-1763
Safran P (1990) Drifting seaweed and associated ichthyofauna: Floating nursery in the Tohoku waters La Mer 28:225-239

Safran P, Omori M (1990) Some ecological observations on fishes associated with drifting seaweed off Tohoku coast, Japan. Mar Biol 105: 395-402

Sakakura Y, Tsukamoto K (1997) Age composition in the schools of juvenile yellowtail Seriora quinqueradiata associated with drifting seaweeds in the East China Sea. Fish Sci 63:37-41

Sano M, Omori M, Taniguchi K (2003) Predator-prey systems of drifting seaweed communities off the Tohoku coast northern Japan, as determined by feeding habit analysis of phytal animals. Fish Sci 69:260-268

Senta T (1965) Importance of drifting seaweeds in the ecology of fisheries. A series of studies on fisheries 13 Japan Fish Resour Conserv Assoc, Tokyo, pp1-54 (in Japanese)

Tala F, Gómez I, Luna-Jorquera G, Thiel M (2013) Morphological, physiological and reproductive conditions of rafting bull kelp (Durvillaea antarctica) in northern-central Chile $\left(30^{\circ} \mathrm{S}\right)$. Mar Biol 160:1339-1351

Thiel M, Gutow L (2005) The ecology of rafting in the marine environment. I. The floating substrata. Oceanogr Mar Biol Ann Rev 42: $181-264$

Thiel M, Hinojosa IA, Joschko T, Gutow L (2011) Spatio-temporal distribution of floating objects in the German Bight (North Sea). J Sea Res 65:368-379

Thomas L, Buckland ST, Rexstad EA, Laake JL, Strindberg S, Hedley SL, Bishop JRB, Marques TA, Burnham KP (2010) Distance software: design and analysis of distance sampling surveys for estimating population size. J Appl Ecol 47:5-14

Thomas L, Buckland ST, Burnham KP, Anderson DR, Laake JL, Borchers DL, Strindberg S (2002) Distance sampling. Encyclopedia of Environmetrics 1:544-552

Tseng CK (1983) Common seaweeds of China. Sci Press, Beijing

Vandendriessche S, De Keersmaecker G, Vincx M, Degraer S (2006) Food and habitat choice in floating seaweed clumps: the obligate opportunistic nature of the associated macrofauna. Mar Biol 149: 1499-1507

Witherington BE (2002) Ecology of neonate loggerhead turtles inhabiting lines of downwelling near a Gulf Stream front. Mar Biol 140:843-853

Yamamoto T, Ino S, Kuno M, Sakaji H, Hiyama Y, Kishida T, Ishida Y (2007) On the spawning and migration of yellowtail Seriola quinqueradiata and research required to allow catch forecasting. Bull Fish Res Agency 21:1-29 (in Japanese)

Yatsuya K (2005) Studies on production and outflow process of Sargassum Forest Kyoto I Oceanic. Fish Sci Spec Rep 7:41pp (in Japanese with English abstract)

Yatusya K (2008) Floating period of sargassacean thalli estimated by the change in density. J Appl Phycol 20:797-800

Yoshida T (1963) Studies on the distribution and drift of the floating seaweed. Bull Tohoku Reg Fish Res Lab 23:141-186 (in Japanese with English abstract)

Yoshida T (1998) Marine algae of Japan. Uchida Rokakuho, Tokyo

Zhu J, Chen C, Li C, Lin H (2004) Does the Taiwan warm current exist in winter? Geophys Res Lett 31, L12302. doi:10.1029/2004GL019997 